\title{
Peroxisome Biogenesis Disorder 4A
}

National Cancer Institute

\section{Source}

National Cancer Institute. Peroxisome Biogenesis Disorder 4A. NCI Thesaurus. Code C155754.

An autosomal recessive condition caused by mutation(s) in the PEX6 gene, peroxisome assembly factor 2 . Peroxisome biogenesis disorder $4 \mathrm{~A}$ manifests phenotypically as Zellweger syndrome. 